\title{
Local Normal Universities and Colleges of Undergraduate Course Engineering Talents Cultivation Plan Orientation
}

\author{
Gao Shuxia $^{1}$, Wang Deyi ${ }^{2}$, Zhang Peng ${ }^{2}$, Guo Xianjun ${ }^{2}$, Zhang Xiaolong ${ }^{2}$ \\ (1. Department of Opt-electric Information Technology, YanTai University, Yantai 264005, \\ People's Republic of China \\ 2. Department of environment and materials engineering of YanTai university, YanTai264005, \\ People's Republic of China) \\ * Corresponding Author
}

\begin{abstract}
The passage focuses on the basic connotation of life vocational career, the training concept of local universities and colleges of undergraduate course engineering talents, talent objective orientation and talent training mode are deeply analyzed and discussed. This paper introduces the courses of general education, the basic framework of talent training scheme and the thinking and practice experience about science and technology innovation activities of college students.
\end{abstract}

Keywords-occupation career, the talent training scheme, general education, science and technology innovation, thinking

\section{INTRODUCTION}

With the expansion of higher education, higher education in China has turned from elite education into the popular education, the number of university graduates to innovate repeatedly tall, 2010 national university graduates reached 6300000, and 2011 reached 6500000. University Graduates' employment has become a hot issue concerned by the society and the school. At present, the related concept of education and professional training scheme of the teaching reform around the college student occupation career cultivation also get more and more attention of people. As the local colleges and universities educators, in last few years, aiming at the local colleges and universities teaching task and characteristics of education, a in-depth theoretical thinking and beneficial exploration and practice was put into the professional engineering personnel training idea, talent cultivation objective orientation and talent training mode, this article only give the local colleges and universities of engineering reflections on the orientation of talent training plan to the colleagues for discussion.

\section{CONNOTATION OF COLLEGE STUDENT OCCUPATION CAREER}

Life occupation can be divided into three levels: the first level is the level of employment, only to maintain basic need of life, is the lowest level of occupation career; the second level is occupation, this lever will have stable work, able to meet basic material needs; the third level is business, the level not only have rich material life, but also with the spiritual satisfaction. These three levels are gradational advance, progressively implementation, it is not possible in one step.
Life occupation career can be divided into external occupation career and internal occupation career, and foreign occupation career is the combination and change of factors, such as, unit of work, working content, working environment, job and salary. Internal occupation career is the combination and change of factors, such as, basic knowledge, ideas, psychological quality, basic skills, feelings need to have when engaged in an occupation. the various factors needed by internal occupation career, can be achieved with the help of others, but most of them should be achieved through their own efforts. the different between external occupation and internal occupation career is that all aspects of internal occupation career once owned, others are not entitled to also cannot be retracted or deprivation. The rising of the factors of internal occupation career will inevitably promote the healthy development of foreign occupation career, it is a key factor in man's occupation career and life success. Thus, full attention shall be paid to acquire all aspects of effective access of internal occupation career in the occupation career stages.

\section{MISUNDERSTANDINGS IN LOC AL COLLEGES AND UNIVERSITIES PERSONNEL TRAINING REFORM}

Employment guidance is a very real power, it affects the school various important decisions directly. under the pressure of the guidance of employment, utilitarian tendency of undergraduate education has emerged, it is changing the traditional relationship between schools and students. nowadays students learning their own professions and achievement with a strong utilitarian attitude. And schools have begun consciously or unconsciously adjust the personnel training objectives and teaching plan. based on the reality or interest considerations At present, domestic occupation career planning education are mostly still in the first level, many local colleges and universities personnel training programs is only focus on how to deal with the fierce employment competition, which has a great relationship with current college management system and operation mechanism. In this mode of operation and social environment, many local colleges and universities only execute simple volume control index on students' employment, and the quality of employment and occupation of sustainable development will not take into account.

One of the representative training modes is trying to develop the graduates of "specialist plus generalist ", and 
calling this the general education. The general education curriculum is translated into popular literacy curriculum, it has deviated from the basic purpose of general education. In many schools, besides a major, students also have a minor in a wide variety of courses, It is hope that the model can make students to form wide adaptation knowledge structure of employment. Therefore, students must learn a lot of basic theory course, be busy with a variety of examination, That is the so-called coping with changeless which should be 10 thousand changes. This teaching model reflects the dream of an education for life, itself has deviated from the idea of lifelong education. The formal academic education is very limited, because of the limitation, so it is not the end. In fact, a person's knowledge structure always are adjusting, any professional training program is not likely to finish a student's life-long knowledge structure in four years.

Another representative of the training mode is emphasis on qualifications skills, while practice ability training is ignored. In order to improve the employment competitiveness of students, part of the professional in some schools introduced undergraduates to participated in the occupation qualification training and examination, occupation qualification certificate has gradually become the evaluation of undergraduate teaching whether adapted to the economic, social and market development or not. Some schools have curriculum related to the occupation qualification certificate examination into the undergraduate professional training program, this approach will interfere with the system and integrity of original subject seriously, It also greatly increase the burden of students. It shall be known that only with the occupation qualification certificate is not enough, the students' practice ability and innovation ability training must be strengthened.The cultivation of healthy people, should be a primary mission of education, which is a more fundamental task than the occupation qualification skills.

One representative of the training mode is blind model famous colleges talent training mode. Some schools are vigorously promote the" research teaching" and" research learning", in the hope that the undergraduate education students can learn to academic way of thinking. While it is a very necessary accomplishment, but for local colleges and universities this isn't a dose of good medicine.

\section{THOUGHT OF THE PERSONNEL TRAINING MODE ABOUT ENGINEERING MAJORS IN LOCAL UNIVERSITIES}

Mr. Yang Shuzi in"some thoughts on the strategy of the development of universities " proposed that serious problems exist in the development of Chinese higher education reform, heavy Polytechnic light humanities, professional light based, ISBN light practice, common light character, heavy utility light quality, it is think that Chinese higher education should cultivate" thick knowledge based, strong ability, high quality, wide caliber" talent [1]. The author thinks that the colleges and universities must adapt to the needs of economic construction and social development actively, deepening the talent training mode and the reform of talents training program, improve the quality of talent cultivation effectively. The spirit of innovation shall be reflected in the education reform, the full implementation " teaching quality of college and teaching reform project" of the
Ministry of Education. The ideas of quality education shall be embodied to adhere to impart knowledge, build capacity, improve quality coordinated development and strive to improve the students' learning ability, practical ability and innovative ability.

\section{A.thought of the general education curriculum}

General education is not equal to the popularity of certain knowledge of a subject, in order to receive expected effect and achieve the general education course objective [2], a high level teaching and discussion shall be put forward in the process of teaching general education curriculum. For example, a humanities professor to open literature appreciation course for environmental science and engineering students, then, his purpose is not only popularize general knowledge of literature, introduction of famous works to students, they also should make the students follow it into the realm of literary appreciation and learn the way of thinking about literary works, and use it to look at the problems, analysis problems. Another example is environmental science and engineering professor open course of environmental protection and sustainable development for the other college students, is not only just to make the other faculties and students understand general knowledge of environment protection, and they should expand the presence of global problems in environmental protection, make the students know that the problem in environmental protection development history is how presented, where they occur during the evolution, the basic method of thinking and solving problem and so on, from which scientific thought idea and realm can be achieved, students understand the dimensions of scientific thinking, understanding the realm human thought in natural reached, experience interest in science study. This course is not to give up professional standards, and reached to a considerable depth of thought. The author thinks that this should be the goal for every general education teachers to pursuit.

Although general education curriculum not pure knowledge, but certain knowledge is needed to serve as the base material, the aim is to form the thought and academic experience. General education curriculum in nature can be summarized into three points: experience, practice and discussion [3]. These three points are built around a central goal, which makes the students to obtain independent academic thinking ability and understanding on the world and life through the study of course.

\section{B.thought of the basic framework of personnel training plan}

From the basic trend of the higher education development and the trend of supply and demand change of labor market, in a long time, the competition between graduates and other job seekers will be more intense. There is a big gap, compared with famous brand school, key university, local colleges and universities in many aspects, such as, education resources occupation, social reputation and influence Whereas the employer hold different " levels" concept in recruitment. This determines the local colleges and universities graduate and the key university graduates in different starting line in employment market, which increased the employment difficulty of local undergraduate college graduates [4]. Therefore, taking employment as the direction, deepening 
the talent cultivation plan and the talent cultivating pattern enhance the competitiveness of graduates in employment has become a request inevitably for sustainable development for local undergraduate colleges.

First of all, talent training program should be conducive to students' academic spirit cultivation. The task of education Local colleges and universities bear is cultivating the subject academic masters, but students should at least have certain academic ability and scientific thought. Although their major and knowledge structure may not directly in line with the occupation career needs, but in their professional study in the academic accomplishment, independent thinking ability and the spirit inspired,can make they have a solid foundation of theory, strong practical ability and thinking ability and freely, and that everything are more precious than limited professional knowledge and skills. On the undergraduate education, students learn in the academic way of thinking, it is a very necessary cultivation [4]. Even his later work may not be in the major field of study, but he can be a spirit of academic worker, he can be a scholar's attitude to think in practical work, he will have higher view and analyze and solve problems train of thought and method than general practitioners.

Secondly, talent training program should have a reasonable value orientation. Any form of education is to cultivate a certain knowledge of reserve forces, local colleges and universities undertake two tasks, one is to transport outstanding research talents for other universities or research institutions, the other is to transport advanced application type talents for the local social and economic development. To tell from this meaning, undergraduate education is not fully equivalent to the employment education, undergraduate education still has some not for employment by the inclusion of the higher level institutions conveying research ability and some other social and cultural functions. From social functions or from the personal needs, it is likely to be the local undergraduate education personnel training plan of value orientation, the key issue is the starting point of employment guidance. Employment is related to the great beneficial to the people's livelihood, but first of all, the education should be the activities of cultivating people, must fully reflect the education main body status. If just from the economic and social development point of launch employment orientation, it is regarded as the efforts through which government or schools solve the employment problem, such "employment oriented"seems somewhat utilitarian, in the process of education, it is also prone to bias, even being misinterpreted as" employment rate oriented" [5] (which is now do exist ). The dominant position of the students can not just a slogan, but should be carried out to the school the education practice, students dominant position means that the education is not only the knowledge teaching, but also should take full account of the differences between individuals to teach students in accordance with their aptitude. In the process of the construction of professional curriculum system and optimization ,no matter structure mode selection, professional orientation, or from the common course, basic disciplinary courses, professional courses, and professional direction of Elective Elective Course and the teaching practice etc, should give full consideration to the students all-round development and personality differences. Establishment the education system including of curriculum system, which can reflect the students' subject position. Provide greater selectivity space for the students' autonomous learning, and the development of personalities .

Thirdly, talent training scheme must pay full attention to the practice teaching link. Local colleges and universities bear the primary task provides service for the local social and economic development, students' mainstream should be cultivated as "going down, staying down, using" senior applied talents. Therefore in the talent training scheme and curriculum system construction process, attention should be paid not only to professional theoretical system of relative integrity, and not because of too much emphasis on a complete theoretical system and neglect the training of students' comprehensive ability and training. The training target should be focused on to hold a relatively complete system of subject knowledge and comprehensive ability of these two basic points. The comprehensive ability includes the ability of understanding and development, ability of practice and innovation, competition and cooperation and so on. Therefore in the process of construction and optimization of the curriculum system, great importance must be attached to practice teaching, improve the curriculum design, experiment and practice on the training plan of the hours and credits proportion, effectively guarantee the quantity and quality of practice teaching.

\section{C. thought of the driving effect on to play students' science and technology innovation}

The professional education goal is not only to teach the students with the professional knowledge and professional skills, the more important goal is to let the students get into a field and deep thinking, problem and problem-solving ideas and methods, its value is mainly manifested in the academic spirit fostering. In the undergraduate stage, students learn the academic way of thinking and the design of the solution of a problem, it is a very necessary accomplishment. Students in one study obtained in the process of thinking, rigorous style and found the problem to solve the question ability, will become his lifelong quality. Through practice, the author thinks that increasing undergraduate science and technology innovation efforts in this respect, can receive the twice the result with half the effort. After the students entering the professional foundation course of study, they already preliminary had engaged in the research work of basic theoretical knowledge, in this term, if the students can integrate into the teacher's research team, they will turn from initially curious to research interest, and stimulate their enthusiasm of deep research, discovering a problem and proposing various solutions, they will find more time to browse, complementary the various aspects of knowledge in study process. After 2-3 years of continuous efforts, their innovative consciousness, innovative ability, practical ability, problem solving and analytical skills and teamwork spirit will significantly improve. Of course, students' interests or consciousness is not enough to scientific and technological innovation activities, it is needed to establish a relatively sound management mechanism and management method. The approach is to set up the 
undergraduate innovation fund project, with students special interests as the starting point, to stimulate students' innovative thinking and innovative consciousness, to foster an innovative practice ability in the applied talents as the goal, focus on a group of undergraduate research learning and innovative experiment project. Talent training program, on science and technology innovation contest (contest), academic papers, research activities, invention patents should be given the recognized credits, and the practice of innovation of science and technology should be put into the credit management. Under the protection of this system students' science and technology innovation activity will be more durable, more vitality.

\section{REFERENCES}

[1] Yang Shuzi stands beforehand, do not abandon beforehand about University - Reflections on the development strategy of $[\mathrm{J}]$. higher education research,1998(1):11-12

[2] Wang Fangliang Yang Biwu. Zhang Guangjie, general education quality restriction factor analysis - from the perspective of curriculum implementation [J]. Journal of Anqing Teachers College ( SOCIAL SCIENCE EDITION ),2010(12)

[3] paint parvenu, institute organization mode on the basis of general education in the University $[\mathrm{J}]$. Heilongjiang higher education research,2008(10)
[4] high Weizhong, on optimizing teaching of local universities' curriculum system [J]. Journal of Shaoguan University ( SOCIAL SCIENCE ),2008,29(10):130-132.

[5] Wang Defeng, from the perspective of University General Education in the direction and path[J]. Fudan Education Forum,2006,4(4):25-28.

[6] Liu Chunsheng, Zhang Yu. On the occupation education" employment oriented " when to think[J]. Vocational Education Forum,2005,10(28):4-6.

[7] Song Na, Wang QunHui, Li YueFang, Li TianXin. Environmental Engineering Specialty Teaching Reform[J]. China Metallurgical Education.2014(01):31-32.

[8] Hou Pin, Wang JiabBing, Wang ChunRong, Zhang LiPing. Reform of Environmental Engineering Specialty Experiment Teaching in coal University $[\mathrm{J}]$.Chinese modern educational equipment, 2015(07)

[9] Li XiaoPing, Feng LinNa. The system construction, reform and practice of the chemical course system of Environmental Science Specialty in Colleges and Universities[J].Higher education of Sciences, 2012(02):146-150.

[10] Liang Bo. Research on the construction of environmental general education system in Local Undergraduate Colleges[J].Higher education of Sciences, 2014(06):82-86. 